\title{
Epidemiological studies on subclinical mastitis in dairy goats in northern regions of Bangladesh M.I.A. BEGUM ${ }^{1}$, M. S. HOSSAIN ${ }^{2}$, M. ERSHADUZZAMAN ${ }^{3}$ and M. S. ALAM ${ }^{3}$ \\ ${ }^{1}$ Associate Professor, Dept. of Animal Husbandry and Veterinary Science, University of Rajshahi, Bangladesh \\ ${ }^{2}$ Professor, Dept. of Genetic Engineering and Biotechnology, University of Rajshahi, Bangladesh \\ ${ }^{3}$ Senior Scientific Officer and Scientific Officer, Goat and Sheep Production Research Division, Bangladesh Livestock Research Institute, Savar, Dhaka, Bangladesh. \\ *Corresponding author's Email: iakalpona@gmail.com
}

\begin{abstract}
A cross sectional study was carried out from June, 2008 to December, 2010 to estimate the prevalence of subclinical mastitis and to determine the responsible bacterial pathogens in lactating dairy goats in northern districts of Bangladesh. A total of 292 goats and 584 udder halves milk samples were screened using California Mastitis Test (CMT). Prevalence of subclinical mastitis at goat level was $56.2 \%$ (164/292), and in udder half level it was 33.9\% (198/584). The subclinical mastitis prevalence at goat level was high (71.6\%) in Jamnapari goats as compared to Black Bengal goats $(50.2 \%)$, whereas at the udder half level, subclinical mastitis prevalence was $45.1 \%$ and $29.6 \%$ in Jamnapari and Black Bengal goats, respectively. The pathogens isolated from subclinical mastitic milk samples were coagulase negative Staphylococci, Coliforms, Streptococcus spp., Staphylococcus aureus, Micrococcus spp., Pseudomonas aeruginosa and Bacillus cereus. Among these, the most frequent isolates were coagulase negative Staphylococci (28.8\%), Coliforms (22.7\%) and Streptococcus spp $(15.2 \%)$. Out of four potential host related risk factors considered, litter size and body condition of goats were found to influence the prevalence rate of subclinical mastitis in goat significantly ( $p$ < $0.05)$. On the other hand, the subclinical mastitis was very significantly $(p=0.0001)$ associated with the housing system of goats, i.e., goats reared in raised floor had a low subclinical mastitis infection rate $(35.8 \%)$ as compared to reared in earth floor $(62.2 \%)$. Antibiogram studies were also performed for the bacterial isolates and Gentamicin was found to be the most effective drug.
\end{abstract}

Key words: Antibiogram, California Mastitis Test (CMT), mastitis, prevalence, risk factors

\section{Introduction}

Mastitis is a persistent, inflammatory reaction of the udder tissue. It is the most common costly disease in dairy animals worldwide (Harmon, 1994). Dairy goats produce about 15.2 million metric tons (MT) of milk, accounting for about $2 \%$ of the world total amount of milk produced by livestock species, the largest amount of goat milk is produced in India, followed by Bangladesh and Sudan (FAOSTAT, 2008). The dairy goat industry is rapidly gaining in importance throughout the world in recent years. Among the several problems hindering the livestock development in Bangladesh, disease problems constitute a severe threat to the successful production of livestock and its industry. Therefore, any factor that adversely affects the quantity and quality of cattle and goat milk is of great financial interest. Milk quality is mainly affected by bacterial contamination of the mammary gland, which causes 
clinical or subclinical mastitis (Boscos et al. 1996). Mastitis is defined as an inflammation of the mammary gland, affects lactating animals including cattle, goats, sheep, buffaloes and camels and is almost always associated with bacterial infection. Mastitis in the goat is mainly subclinical (Contreras et al. 1995 and McDougall et al 2002). It is one of the major problems of the dairy industry worldwide including Bangladesh. Subclinical mastitis is considered more severe than clinical mastitis, as early detection is impossible without regular monitoring. Subclinical mastitis is characterized by no visible sign of disease, apparently normal milk, with an increase in somatic cell count (SCC) that is bacteriologically positive (Blowey and Edmondson 1995). Subclinical mastitis results in decreased milk yield in goat in consequence growth retardation and higher mortality rate among suckling kids. The California Mastitis Test (CMT) developed by Schalm and Noorlander (1957) has been routinely used to evaluate the content of leucocytes and epithelial cells, defined as the somatic cells (SC), in milk. The CMT was also chosen in several investigations because it is more perfect, efficient and reliable than other field and chemical tests for diagnosis of subclinical mastitis (El-Balkemy et al. 1997). The primary causes of subclinical mastitis in goats are Staphylococcus spp., Streptococcus spp. and Micrococcus spp. (Boscos et al. 1996; Ndegwa et al. 2001). All immunization procedures developed against mastitis have remained unsuccessful due to its multiple etiological agents. Antibiotic therapy is an important tool in the scheme of mastitis control. The treatments are more effective when directed by veterinarians; for example correct drug selection can be enhanced using an appropriate antimicrobial susceptibility test. The misuse or intensive use of antibiotics can lead to the development of resistance among different bacterial strains. Therefore, regular studies on antibiotic sensitivity of bacterial isolates are mandatory for effective and economical treatment of the disease (Sanchez et al. 1988). Although milk is a very nutritional food that is rich in carbohydrate, proteins, fats, vitamins and minerals but health risk to consumers can be associated with milk, due to the presence of zoonotic pathogens and antimicrobial drug residues (Bradely, 2002).

Due to the above mentioned economic and public health importance, this study was designed to estimate the prevalence of subclinical mastitis in apparently healthy dairy goats, to elucidate the associated risk factors and to find out the most frequently causative agents causing IMI, and to do antibiogram of the major bacterial pathogens from milk samples of mastitic goats. 


\section{Study area and period}

\section{Materials and Methods}

Field survey for the prevalence of subclinical mastitis was done at all the northern districts (both Rajshahi and Rangpur division) of Bangladesh. All the laboratory investigations were conducted at the Molecular Biology Laboratory of Institute of Biological sciences, Universitity of Rajshahi, Bangladesh. The study was conducted for the three years period of from June, 2008 to December, 2010.

\section{Study design}

This was a cross-sectional study whereby study animals were selected randomly and inclusion criteria were that all apparently healthy lactating dairy goats were eligible for the study.

\section{Study population}

The study was conducted on 292 dairy goats belonging to private and house hold goat farms in all districts of Rajshahi and Rangpur division of Bangladesh. Of all 292 dairy goats, Black Bengal goats and high yielding Jamnapari goats were included, as 211 Black Bengal goats and 81 Jamnapari goats.

\section{Questionnaire based data collection}

The data were collected in a questionnaire specifically designed for this purpose. The questionnaire was pre-tested prior to their final use. The questionnaire was administered to the participating farmers, who answered questions about farm management and animal husbandry practices including host and environmental factors influencing the incidence of mastitis.

\section{Physical examination of milk sample}

Immediately after collection, milk samples were subjected to physical examination with naked eyes to detect any abnormalities in color, odor, consistency, presence of blood and clot, flakes and any other visible abnormalities.

\section{Collection of milk sample}

Milk sample was collected from 198 udder halves of goat. Before collection of sample each teat was thoroughly disinfected with cotton swabs and $70 \%$ alcohol. Special attention was paid to the teat ends. Sterile sample tubes which had been color-coded per-udder half were used. After disinfection, a few $\mathrm{ml}$ of milk from each udder half were milked into the corresponding sample tubes. Care was taken so that no contact was made between the stream of milk and the milker's hands. The tubes were held as horizontally as possible to minimise the entry of dust. The sterile rubber stoppers were held in such a way that they would not be contaminated. After taking samples from each udder half, the goat identification number was marked on each tube with a water proof marker pen. The tubes were transported on ice box to 
Molecular Biology Laboratory of the Institute of Biological Sciences, University of Rajshahi, where they were stored at $-20^{\circ} \mathrm{c}$ until cultured on standard bacteriological media.

\section{California Mastitis Test (CMT) kit}

CMT kit (Leucocytest ${ }^{\circledR}$, Synbiotics Corporation-2, rue Alexander Fleming -69007 Lyon, France and marketed by Advance Chemical, Co. Bangladesh Ltd.) was used in this study (Plate 3.2). The Leucocytest reagent is composed of Alkyl Aryl sulfonate (3\%), sodium hydroxide $(1.5 \%)$ and bromocresol purple $(1: 10,000)$ as an indicator.

\section{California Mastitis Test (CMT)}

Subclinical mastitis was diagnosed based on CMT results and the nature of coagulation and viscosity of the mixture (milk and CMT reagent), which show the presence and severity of the infection, respectively (Harmon, 1994). Before sample collection for bacteriological examination, milk samples were examined for visible abnormalities and were screened by the CMT according to Quinn et al.. (1999). From each udder half, a squirt of milk sample was placed in each of the cups on the CMT paddle and an equal amount of 3\% CMT reagent was added to each cup and mixed well. According to the visible reaction of the CMT, the results were classified into four scores: Negative (no change in consistency), Trace (slightly positive), 1(mild positive) 2(Moderate positive) and 3(highly positive). Scores depend on the degree of gellation that was indicated by gelatinous mass in proportion to severity of infection present (Schuppel and Schwope, 1998).

\section{Bacteriological cultures}

Each CMT positive milk sample was separated under aseptic conditions in labeled sterile screw caped bottles. All milk samples were sent directly to the laboratory with a minimum of delay for routine culture techniques. Milk samples were cultured onto $10 \%$ sheep blood agar and MacConkey agar plates. Suspected colonies were identified morphologically, microscopically and biochemically according to Hargital et al. (1992).

\section{Antibiotic sensitivity test}

Antibiotic susceptibility test was performed using the Kirby-Bauer disc diffusion method (Bauer et al. 1966). Disc diffusion test is based solely on the presence or absence of a zone of inhibition around the antibiotic containing discs. Disc diffusion test were performed and interpreted according to the recommendations of the National Committee for Clinical and Laboratory Standard (NCCLS, 2001) by using Oxide discs impregnated with specific antibiotics. Statistical analysis of the experimental data

Factors that usually affect the prevalence of subclinical mastitis were recorded and were analyzed by using SPSS (Statistical Package for the Social Sciences) version 17.0 software and statistically significant associations were determined by the chi-square test.

\section{Statistical analysis of the experimental data}


Factors that usually affect the prevalence of subclinical mastitis were recorded and were analyzed by using SPSS (Statistical Package for the Social Sciences) version 17.0 software and statistically significant associations were determined by the chi-square test.

\section{Results}

\section{Prevalence of subclinical mastitis in goat}

Among 584 udder halves milk of 292 goats were examined for the diagnosis of subclinical mastitis and in doe level subclinical mastitis was found to be $56.2 \%$.

\section{Prevalence of subclinical mastitis in different breeds of goat}

In case of goat level in Black Bengal and Jamnapari goats subclinical mastitis prevalence was found to be $50.2 \%$ and $71.6 \%$ respectively using CMT. Where as in udder half level subclinical mastitis prevalence was found to be $29.6 \%$ in Black Bengal goats and was $45.1 \%$ in Jamnapari goats. The result revealed that subclinical mastitis prevalence was significantly $(p<0.05)$ influenced by the breed of goats both at doe and udder half levels.

Table 1: Prevalence of subclinical mastitis in different breeds of goat

\begin{tabular}{|c|c|c|c|c|c|c|c|c|}
\hline \multirow[t]{2}{*}{ Host } & \multicolumn{3}{|c|}{ Goats Level } & \multicolumn{3}{|c|}{ Udder halves Level } & \multirow{2}{*}{$\begin{array}{c}\text { Chi- } \\
\text { square } \\
\text { Value }\end{array}$} & \multirow{2}{*}{$\begin{array}{c}\text { Sig. } \\
\text { Level }\end{array}$} \\
\hline & $\begin{array}{l}\text { Total } \\
\text { goats }\end{array}$ & $\begin{array}{c}\text { infected } \\
\text { goats }\end{array}$ & $\begin{array}{c}\% \\
\text { infected }\end{array}$ & $\begin{array}{l}\text { Total } \\
\text { Udder } \\
\text { halves }\end{array}$ & $\begin{array}{c}\text { infected } \\
\text { udder } \\
\text { halves }\end{array}$ & $\begin{array}{c}\% \\
\text { infected }\end{array}$ & & \\
\hline Black Bengal & 211 & 106 & 50.2 & 422 & 125 & 29.6 & & \\
\hline Jamnapari & 81 & 58 & 71.6 & 162 & 73 & 45.1 & & \\
\hline Total & 292 & 164 & 56.2 & 584 & 198 & 33.9 & 11.19 & $* *$ \\
\hline
\end{tabular}

**significant at $1 \%$ level $(p<0.01)$

\section{Risk factors of subclinical mastitis in goat}

In the present study in case of goat out of the different potential risk factors, litter size, parity, stage of lactation and body condition in addition to the environmental factors were studied. These factors were considered in chi-square statistical analysis test to find out their effects on the frequency of subclinical mastitis infection of lactating goats.

\section{Host factors influencing prevalence of sub-clinical mastitis}

Out of four potential host related risk factors considered (Table 2 such as litter size and body condition of goats were found to be significantly $(p<0.05)$ influencing the prevalence rate of subclinical mastitis in goat.

Goats with three kids had a significantly low subclinical mastitis infection rate $(41 \%)$ as compared to that with single kid $(64.7 \%)$. The result also revealed that subclinical mastitis was significantly $(p=0.0001)$ influenced by the body condition of goats (Table 2). Goats of good body condition group had a significantly low subclinical mastitis (39.5\%) as compared to poor body condition group (69.1\%). Parity and stage of lactation were not significantly associated with prevalence of sub-clinical mastitis $(p>0.05)$. 
Table 2: Prevalence of subclinical mastitis of goat in relation to host factors

\begin{tabular}{|c|c|c|c|c|c|c|c|c|}
\hline \multirow[t]{2}{*}{ Risk factors } & \multicolumn{3}{|c|}{ Goats Level } & \multicolumn{3}{|c|}{ Udder halves } & \multirow{2}{*}{$\begin{array}{l}\text { Chi- } \\
\text { Sq. } \\
\text { Value }\end{array}$} & \multirow{2}{*}{$\begin{array}{l}\text { Sig. } \\
\text { Level }\end{array}$} \\
\hline & $\begin{array}{l}\text { Total } \\
\text { goats } \\
(292)\end{array}$ & $\begin{array}{l}\text { infected } \\
\text { goats }\end{array}$ & $\begin{array}{c}\% \\
\text { infected }\end{array}$ & $\begin{array}{c}\text { Total } \\
\text { Udder } \\
\text { halves } \\
(584)\end{array}$ & $\begin{array}{c}\text { infected } \\
\text { udder } \\
\text { halves }\end{array}$ & $\begin{array}{c}\% \\
\text { infected }\end{array}$ & & \\
\hline \multicolumn{9}{|l|}{ Litter size } \\
\hline 1 & 116 & 75 & 64.7 & 232 & 92 & 39.7 & & \\
\hline 2 & 137 & 73 & 53.3 & 274 & 88 & 32.1 & 7.52 & NS \\
\hline 3 & 39 & 16 & 41 & 78 & 18 & 23.1 & & \\
\hline \multicolumn{9}{|l|}{ Parity } \\
\hline $\operatorname{Few}(\leq 3)$ & 182 & 97 & 53.3 & 364 & 117 & 32.1 & & \\
\hline Moderate(4-7) & 82 & 46 & 56.1 & 164 & 58 & 35.4 & 4.89 & NS \\
\hline $\operatorname{Many}(\geq 7)$ & 28 & 21 & 75 & 56 & 23 & 41.1 & & \\
\hline \multicolumn{8}{|l|}{ Stage of } & \\
\hline $\operatorname{Early}(\geq 1)$ & 117 & 56 & 47.9 & 234 & 65 & 27.8 & & \\
\hline $\operatorname{Mid}(2-3)$ & 101 & 64 & 63.4 & 202 & 79 & 39.1 & 5.74 & NS \\
\hline Late $(\geq 4)$ & 74 & 44 & 59.5 & 148 & 54 & 36.9 & & \\
\hline \multicolumn{9}{|l|}{$\begin{array}{l}\text { Body } \\
\text { condition }\end{array}$} \\
\hline Good & 124 & 49 & 39.5 & 248 & 64 & 25.8 & & \\
\hline Medium & 29 & 19 & 65.5 & 58 & 20 & 34.5 & 24.61 & $* *$ \\
\hline Poor & 139 & 96 & 69.1 & 278 & 114 & 41 & & \\
\hline
\end{tabular}

**significant at $1 \%$ level $(p<0.01)$

$\mathrm{NS}=$ Not significant

\section{Environmental factors affecting subclinical mastitis infection in goat}

\section{Housing}

The result of the present study revealed that subclinical mastitis was significantly $(p=0.0001)$ influenced by the housing system of goats (Table 3). Goats reared in raised floor had a significantly low subclinical mastitis infection rate (35.8\%) as compared to reared in earthen floor $(62.2 \%)$.

\section{Season}

The present study indicated that subclinical mastitis was not significantly $(p>0.05)$ influenced by the season (Table 3). Goats in rainy season had a subclinical mastitis infection rate $57.8 \%$ and in case of dry season subclinical mastitis infection rate was $32.9 \%$.

Table 3: Prevalence of subclinical mastitis of goat in relation to environmental factors

\begin{tabular}{|c|c|c|c|c|c|c|c|c|}
\hline \multirow[t]{2}{*}{ Risk factors } & \multicolumn{3}{|c|}{ Goats Level } & \multicolumn{3}{|c|}{ Udder halves Level } & \multirow{2}{*}{$\begin{array}{c}\text { Chi- } \\
\text { Square } \\
\text { Value }\end{array}$} & \multirow{2}{*}{$\begin{array}{l}\text { Sig. } \\
\text { Leve }\end{array}$} \\
\hline & $\begin{array}{l}\text { Total } \\
\text { goats } \\
(292)\end{array}$ & $\begin{array}{c}\text { infected } \\
\text { goats }\end{array}$ & $\begin{array}{c}\% \\
\text { infected }\end{array}$ & $\begin{array}{c}\text { Total } \\
\text { Udder } \\
\text { halves }(584)\end{array}$ & $\begin{array}{c}\text { infected } \\
\text { udder } \\
\text { halves }\end{array}$ & $\begin{array}{c}\% \\
\text { infected }\end{array}$ & & \\
\hline \multicolumn{9}{|l|}{ Housing } \\
\hline Earthen & 225 & 140 & 62.2 & 450 & 168 & 37.3 & 14.60 & $* *$ \\
\hline Raised & 67 & 24 & 35.8 & 134 & 30 & 22.4 & & \\
\hline
\end{tabular}


Season

$\begin{array}{lcccccccc}\text { Dry season } & 178 & 93 & 52.2 & 356 & 116 & 32.9 & 2.86 & \text { NS } \\ \text { Rainy season } & 114 & 71 & 62.3 & 228 & 132 & 57.8 & & \end{array}$

**significant at $1 \%$ level $(p<0.01)$

$\mathrm{NS}=$ Not significant

\section{Bacterial isolates of subclinical mastitis infected goat milk}

Milk samples were collected from 198 udder halves of 164 lactating goats. Of all udder half samples, 186 (93.9\%) samples were culture positive and $12(6.1 \%)$ samples yield no bacterial growth. Isolates from positive cases were 57 (28.8\%) coagulase negative Staphylococci (CNS), 45 (22.7\%) Coliforms, 30 (15.2\%) Streptococcus spp., 19 (9.6\%) Staphylococcus aureus (CPS), 14 (7.1\%) Micrococcus spp., 11 (5.6\%) Pseudomonas aeruginosa, and 10 (5.1\%) Bacillus cereus. Most of the subclinical cases were due to coagulase negative Staphylococci (CNS), Coliforms, Streptococcus spp., and Staphylococcus aureus (CPS) (Table 4).

Table 4: Frequency distribution of the different bacterial isolates from the milk samples of subclinical mastitis positive goats

\begin{tabular}{llll}
\hline $\begin{array}{l}\text { Serial } \\
\text { no. }\end{array}$ & Bacterial species & No. of samples & Frequency(\%) \\
\hline 1 & Coagulase-negative Staphylococci (CNS) & 57 & 28.8 \\
2 & Staphylococcus aureus (CPS) & 19 & 9.6 \\
3 & Micrococcus spp. & 14 & 7.1 \\
4 & Streptococcus spp. & 30 & 15.2 \\
5 & Coliforms & 45 & 22.7 \\
6 & Pseudomonas aeruginosa & 11 & 5.6 \\
7 & Bacillus cereus & 10 & 5.1 \\
8 & No Growth & 12 & 6.1 \\
& Total & 198 & 100 \\
\hline
\end{tabular}

\section{Results of antibiotic sensitivity pattern of isolated bacteria}

The antibiotic sensitivity pattens of bacterial isolates are presented in Table 5. In this trial, seven most commonly used antibiotics were used. It is evident from this table that the average sensitivity of the isolates was in descending order to gentamicin, ciprofloxacin, amoxicillin, ampicillin, erythromycin, tetracycline and penicillin. Gentamicin was found to be the most effective and penicillin the least effective against various mastitis pathogens in this study.

Table 5: In vitro antibiotic sensitivity results of the bacterial isolates

\begin{tabular}{|c|c|c|c|c|c|c|c|}
\hline \multirow[t]{2}{*}{ Bacterial isolate } & \multicolumn{7}{|c|}{$\%$ of sensitive isolates against } \\
\hline & $\begin{array}{l}\text { Gentami } \\
\text { cin }\end{array}$ & Ciprofloxacin & $\begin{array}{l}\text { Erythro } \\
\text { mycin }\end{array}$ & $\begin{array}{c}\text { Tetracyc } \\
\text { line }\end{array}$ & $\begin{array}{l}\text { Amoxici } \\
\text { llin }\end{array}$ & $\begin{array}{c}\text { Ampici } \\
\text { llin }\end{array}$ & Penicillin \\
\hline $\begin{array}{l}\text { Staphylococcus } \\
\text { aureus }\end{array}$ & 93.3 & 93.3 & 86.6 & 20 & 80 & 73.3 & 66.6 \\
\hline $\begin{array}{l}\text { Coagulase- } \\
\text { negative } \\
\text { Staphylococci }\end{array}$ & 93.3 & 80 & 86.6 & 33.3 & 73.3 & 60 & 40 \\
\hline Streptococcus spp. & 95 & 90 & 80 & 35 & 75 & 70 & 45 \\
\hline
\end{tabular}




\begin{tabular}{lccccccc}
\hline Coliforms & 85 & 75 & 15 & 45 & 65 & 35 & 0 \\
$\begin{array}{l}\text { Pseudomonas } \\
\text { aeruginosa }\end{array}$ & 85 & 80 & 10 & 45 & 70 & 50 & 0 \\
$\begin{array}{l}\text { Bacillus cereus } \\
\text { Proteus spp. }\end{array}$ & 90 & 80 & 15 & 55 & 65 & 45 & 0 \\
& 85 & 70 & 20 & 45 & 60 & 35 & 0 \\
\hline
\end{tabular}

\section{Discussion}

In the present study overall prevalence of subclinical mastitis was $56.2 \%$ by CMT in the goat population studied. This observed prevalence is close to the result obtained by Poutrel et $a l$. (1997) \& White and Hickley (1999)... what about their observations/values??. But the present report of doe-prevalence of subclinical mastitis is relatively higher than many other workers like Kostelic et al.. (2009) recorded as $20 \%$ and Ndegwa et al.. (2000) as 9.8\%. This may be due to the influence of several factors such as breed differences, age and parity of the animals, stage of lactation and body condition, different management practices followed on each farm (Contreras et al. 1995; Boscos et al.. 1996 and McDougall et al.. 2002).

The present study indicated that prevalence of subclinical mastitis is significantly $(p<0.05)$ influenced by the litter size and body condition of goats, because goats with more kid and poor body condition are usually suffer from malnutrition and energy deficiency as a result easily become the host of infectious agents due to low immunity. Although there was no significant association between the prevalence of subclinical mastitis and stage of lactation, an obvious trend of increasing prevalence rate of subclinical mastitis with the stage of lactation was observed. This result is similar to the finding of East et al.. (1986) who found no association between parity and subclinical mastitis status. Prevalence of caprine subclinical mastitis also appeared to be influenced by farm management system such as type of housing used to raise the goat in the studied area. The prevalence of subclinical mastitis was significantly higher in farms where goat was raised under traditional conditions and had an earth floor (soil surface). Earth floor has been reported to be an important risk factor for subclinical mastitis in goat (Ndegwa et al.. 2000; Megersa et al.. 2010). This observation could be explained by the fact that dirty and wet bedding is a common finding on the earthen floors, tends to harbor a wide range of infectious agents that may contaminate the udder and teats. On the basis of these findings, we can suggest to use semi-intensive farming system with either raised floor or concrete floor to rear goats in order to reduce the prevalence of subclinical mastitis.

In the present study, most of the subclinical mastitis infections were due to coagulase negative Staphylococci species accounting for about $28.8 \%$ of the infections. This finding is in agreement with the result of Leitner et al.. (2001). Though coagulase negative Staphylococci are regarded as minor pathogens and normal inhabitants of mammary gland some studies indicated that coagulase negative Staphylococci could be pathogenic and even cause more mastitis than Staphylococcus aureus.

Other than coagulase negative Staphylococci bacteria, Coliforms, Streptococcus spp, and Staphylococcus aureus (CPS) were the second common pathogens observed in both cattle and 
goat subclinical mastitis infection, considered as environmental pathogens. Higher incidence of environmental pathogens may be due to poor hygienic conditions; these environmental pathogens originate from the cow's environment and infect the udder via the teat canal (Mallikarjunaswamy and Karishina, 1997). These results regarding the distribution of pathogens correspond well with other studies on subclinical mastitis infection in dairy goats throughout the world (Ndegwa et al.. 2001; Leitner et al.. 2004), in which coagulase negative Staphylococci are the predominant organisms isolated from bacteriological positive milk samples. The large proportion of coagulase negative Staphylococci infections is consistent with the absence of clinical IMI, in fact, some authors have proposed coagulase negative Staphylococci as etiological agents of subclinical IMI in goats (Leitner et al.. 2004) and cows (Smith and Hagstad, 1986). In addition, Staphylococcus aureus, whose role in clinical mastitis in goats has been clearly defined (Maisi and Riipinen, 1991) and subclinical infections by Staphylococcus aureus are also common in goats (Moroni et al.. 2004). Finally, it may be said that in this study compared to environmental pathogens a significant number of isolates were contagious pathogens; appropriate milking practice such as milking of affected goats last, use of separate towels to wash and dry and milker's hand hygiene and culling could be feasible options in the control program in this region.

The in vitro antibiogram studies of the bacterial isolates from mastitis milk revealed gentamicin $(90 \%)$ to be most effective drug followed by ciprofloxacin (83\%), amoxicillin (71\%), ampicillin (55\%), erythromycin (49\%), tetracycline(39\%) and penicillin (25\%).

Gentamicin, ciprofloxacin and erythromycin are newer chemotherapeutic agents and are less commonly used for the treatment of mastitis in the area of study resulting in higher efficacy of these drugs. Gentamicin proved to be the drug of choice in this study. Similar antibiogram pattern was reported by Frigerio et al.. (1995). In this study, most of the bacterial isolates showed resistance to penicillin, and tetracycline. Indiscriminate and frequent use of these antibiotics in animals could be the reason for their ineffectiveness against bacterial isolates. Production of plasmids mediated beta-lactamase enzymes is supposed to be mainly responsible for resistance to penicillin. Since, streptomycin has been extensively used along with penicillin for treating mastitis; it may have led to the development of high resistance in bacteria against this antibiotic. Present results regarding tetracycline resistance for Staphylococcus aureus and coagulase negative Staphylococci were similar to those in Finland (Myllys et al.. 1998). A possible explanation for this phenomenon could be that for many years tetracycline has been the most widely antimicrobial class used by the farmers to treat any infection. On the other hand, less effectiveness of amoxicillin to all the isolates may be due to the resistance produced in the bacteria due to extensive use of this antibiotic in goats.

\section{Conclusion}

The prevalence of subclinical mastitis in goats in northern districts of Bangladesh was $56.2 \%$. Coagulase negative Staphylococci were the most common bacterial species associated with subclinical mastitis in goats in these areas. Identified risk factors associated with subclinical mastitis were litter size, body condition and housing system. Present findings suggest that regular screening of animals for subclinical mastitis with some changes in the farm management system could be an effective way to control the clinical mastitis in dairy industry. 


\section{References}

Bauer, A.W., Kirby, W.M.M., Sherris, J.C. and Turck, M. 1966. 1966. Antibiotic susceptibility testing by a standardized single disk method. Am. J. Clin. Pathol., 45:493-496.

Blowey, R. and Edmondson, P. 1995. Mastitis control in dairy herds, an illustrated and practical guide. Farming press books, Ipswich, UK.

Boscos, C., Stefanakis, A., Alexopoulos, C. and Samartzi, F. 1996. Prevalence of subclinical mastitis and influence of breed, parity, stage of lactation and mammary gland bacteriological status on Coulter counts and California mastitis test in the milk of Saanen and autochronous Greek goats. Small Rum. Res., 21:139-147.

Contreras, A., Correlas, J.C., Sierra, D. and Marco, J. 1995. Prevalence and etiology of nonclinical intramammary infection in Murciano-Granadian goats. Small Rum. Res., 17:71-78.

East, N. E., Birnie, E. F. and Farver, T. B. 1986. Risk factors associated with mastitis in dairy goats. Am. J. Vet. Res., 67:63-67.

El-Balkemy, F.A., Esmat, M., Menazie, A. and Farag, A.N. 1997. Evaluation of screening tests used for detection of subclinical mastitis. 4th Sci. Cong. Egyptian Society for Cattle Diseases, Assiut, Egypt. 181p.

FAOSTAT. 2008. http://faostat.fao.org/default.aspx

Frigerio, C., Bettera, S., Scalise, I., Giraudo, J. and Calzolari, A. 1995. Resistencia and antibioticos de cephas de estafilococos aisladasen tres tambos de Cordoba. Argent. Rev. Med. Vet., 76:288-292.

Hargital C., Egyhaze, K. and Markus, G. 1992 Trends of changes in the antibiotics sensitivity of udder pathogenic bacteria. AllatorvosokLapja., 47: 429- 432.

Harmon, R. J. 1994. Physiology of mastitis and factors affecting somatic cell counts. J. Dairy Sci., 77:2103-2112.

Kostelic, A., Cergolj, M., Tariba, B., Rupic, V., Benic, M., Gantner, V. and Stokovic, I. 2009. Prevalence and aetiology of subclinical mastitis in goats. Ital J. Anim. Sci., 8(3):134-136.

Leitner, G., Chaffer, M., Zamir, S., Mor, T., Glickman, A., Winkler, M., Weisblit, L. and Saran, A. 2001. Udder disease etiology, milk somatic cell counts and NAGase activity in Israeli Assaf sheep throughout lactation. Small Rum. Res., 39:107-112.

Leitner, G., Merin, U., Silanikove, N., Ezra, E., Chaffer, M., Gollop, N., Winkler, M., Glickman, A. and Saran, A. 2004. Effect of subclinical intramammary infection on somatic cell counts, NAGase activity and gross composition of goats' milk. J. Dairy Sci., 71:311-315.

Maisi, P. and Riipinen, I. 1991. Pathogenicity of different species of staphylococci in caprine udder. Br. Vet. J., 147:126-132.

Mallikarjunaswamy, M.C. and Murthy, G.V.K. 1997. Antibiogram of bacteria pathogens isolated from bovine subclinical mastitis cases. Ind. Vet. J., 74(10): 885-886.

McDougall, S., Pankey, W., Delaney, C., Barlow, J., Mardough, P.A. and Scruton, D. 2002. Prevalence and incidence of subclinical mastitis in goats and dairy ewes in Vermont, USA. Small Rum. Res., 46:115-121.

Megersa, B., Tadesse, C., Abunna, F., Regassa, A., Mekibib, B. and Debela, E. 2010. Occurrence of mastitis and associated risk factors in lactating goats under pastoral management in Borana, Southern Ethiopia. Trop. Anim. Hlth. Prod., 42(6):1249-55. 
Moroni, P., Vellere, F., Antonini, M., Pisoni, G., Ruffo, G. and Carli, S. 2004. Antibiotic susceptibility of coagulase-negative staphylococci isolated from goat's milk. Int. J. Antimicrob. Agents., 23:637-640.

Myllys, V., Asplund, K., Brofeldt, E., Hirvela-Koski, V., Honkanen-Buzalske, T., Junttila, J., Kulkas, L., Myllykangas, O., Niskanen, M., Saloniemi, H., Sandholm, M. and Saranpaa, T. 1998. Bovine mastitis in Finland in 1988 and 1995-Changes in prevalence and antimicrobial resistance. Acta. vet. Scand., 39:119-126.

NCCLS (National Committee for Clinical Laboratory Standards). 2001. Performance Standards for Antimicrobial Susceptibility Testing. 11th Informational Suppl., NCCLS Document M 100-911. Pennsylvania, USA.

Ndegwa, E.N., Mulei, C. M. and Munyua, S. J. 2000. The prevalence of subclinical mastitis in dairy goats in Kenya. J. S. Afr. Vet. Assoc., 71(1):25-27.

Ndegwa, E.N., Mulei, C.M. and Munyua, S.J.M. 2001. Risk factors associated with subclinical subacute mastitis in Kenyan dairy goats. Israel J. Vet. Med. 56:4.

Poutrel, B., de Cremoux, R., Ducelliez, M. and Verneau, D. 1997. Control of intramammary infections in goats: Impact on somatic cell counts. J. Anim. Sci., 75:566-570.

Quinn, P. J., Carter, M. E., Markey, B. K. and Carte, G. R. 1999. Clinical Veterinary Microbiology. London: Mosby International Limited.

Sanchez, H. S., Ford, C. W. and Yancey, R. J. 1988. Evaluation of antibiotic effectiveness against Staphylococcus aureus surviving within the bovine mammary gland macrophage. J. Antimicrob. Chemother., 21: 773-786.

Schalm, O. and Noorlander, O. 1957. Experiments and observations leading to development of California Mastitis Test. J. Am. Vet. Med. Assoc., 130:199-204.

Schuppel, H. and Schwope, M. 1998. Diagnosis of mastitis using California mastitis test and measurement of electric conductivity. Archiv für Lebensmittel Hygiene., 49:61.

Smith, R. E. and Hagstad, H.V. 1986. Infection of the bovine udder with coagulase-negative staphylococci. Prev. Vet. Med., 4:35-43.

White, E.C. and Hickley, L.S. 1999. Prevalence of mastitis pathogens in goat milk. Small Rum.Res., 33:117-121.

Bradely, A.J. 2002. Bovine mastitis an evolving disease. Vet. J. 164:116-128. 